Images in...

\title{
A dangerous parapharyngeal mass
}

\author{
Manish Gupta, ${ }^{1}$ Monica Gupta ${ }^{2}$ \\ ${ }^{1}$ Gian Sagar Medical College, Chandigarh, Chandigarh, India; \\ 2Department of Medicine, Government Medical College and Hospital, Chandigarh, India
}

Correspondence to Dr Monica Gupta, monicamanish2001@gmail.com

\section{DESCRIPTION}

A 60-year-old female presented with dry cough since 6 months. There was no history of fever, weight loss, anorexia or gastroesophageal reflux disease. There was no history of dysphagia, hoarseness and lump in the throat or peroral bleed. On oropharyngeal examination, there was a pulsatile mass on right posterolateral pharyngeal wall, that is, behind posterior pillar with mild congestion of posterior pharyngeal wall. Doppler sonography revealed tortuous

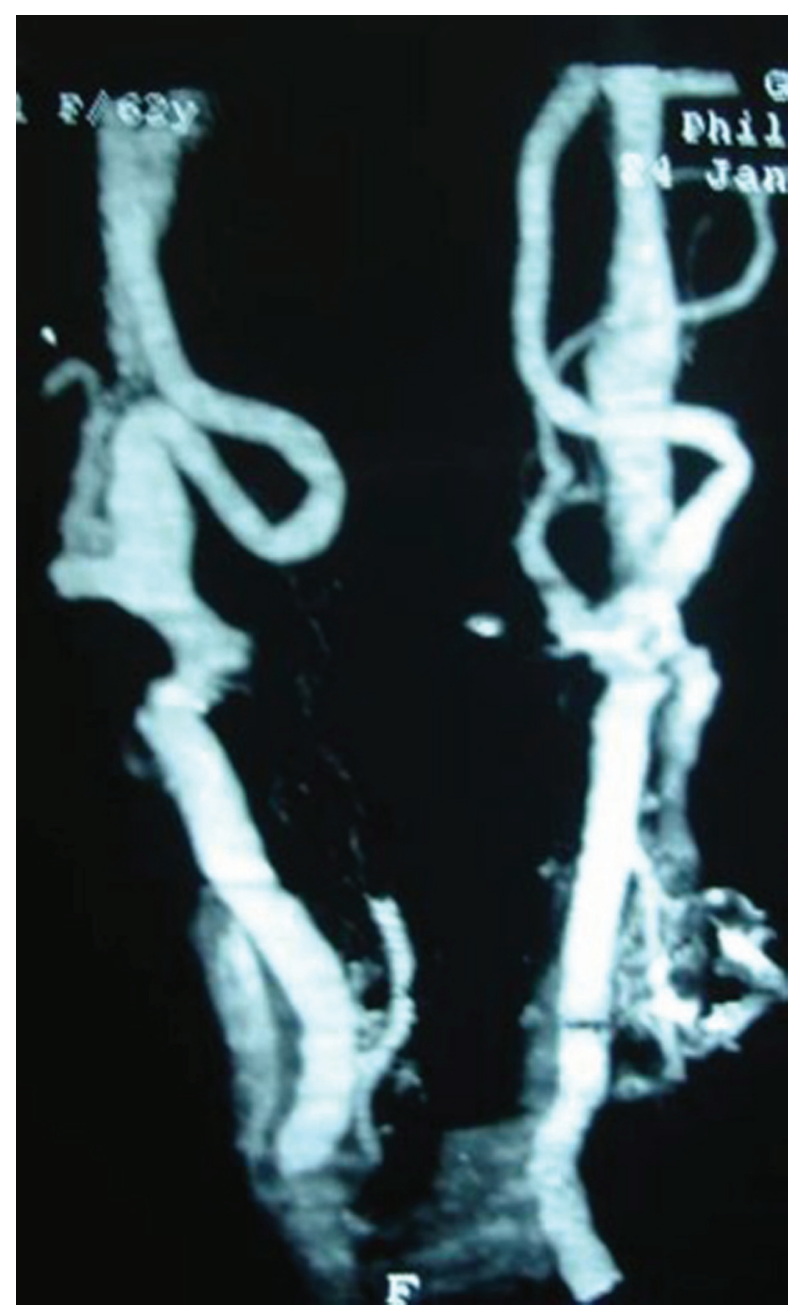

Figure 1 CT angiographic image depicting the aberrant course of extracranial right internal carotid artery (ICA). Right ICA is seen to loop medially, indenting the right posterolateral wall of pharynx at level of palatine tonsils. and medial course of right internal carotid artery (ICA). CT angiography disclosed the course of the right extracranial ICA which was seen to loop medially-reaching upto retropharyngeal space, indenting the right posterolateral wall of pharynx at level of palatine tonsils, that is, C2 vertebra (figure 1). Similarly on axial CT section view, this loop of right ICA is bulging into right pharyngeal wall (figure 2). No evidence of aneurysm was noted. Right common carotid and external carotid arteries were anatomically normal. Left ICA was also normal in course. The blood pressure and other general physical examination were normal.

Common causes of 'pseudo-tumour' in retropharyngeal space are various anatomical variants of internal jugular vein, cervical vertebral osteophytes and muscular lesions besides tortuous and medially-deviated course of internal carotid arteries. Incomplete straightening of ICA during embryological development results in the tortuous or aberrant course, wherein it may indent posterolateral pharyngeal wall. ${ }^{1}$ Such carotid kinking is usually discovered incidentally, during routine head and neck examination. Due to its characteristic location, this anomaly may

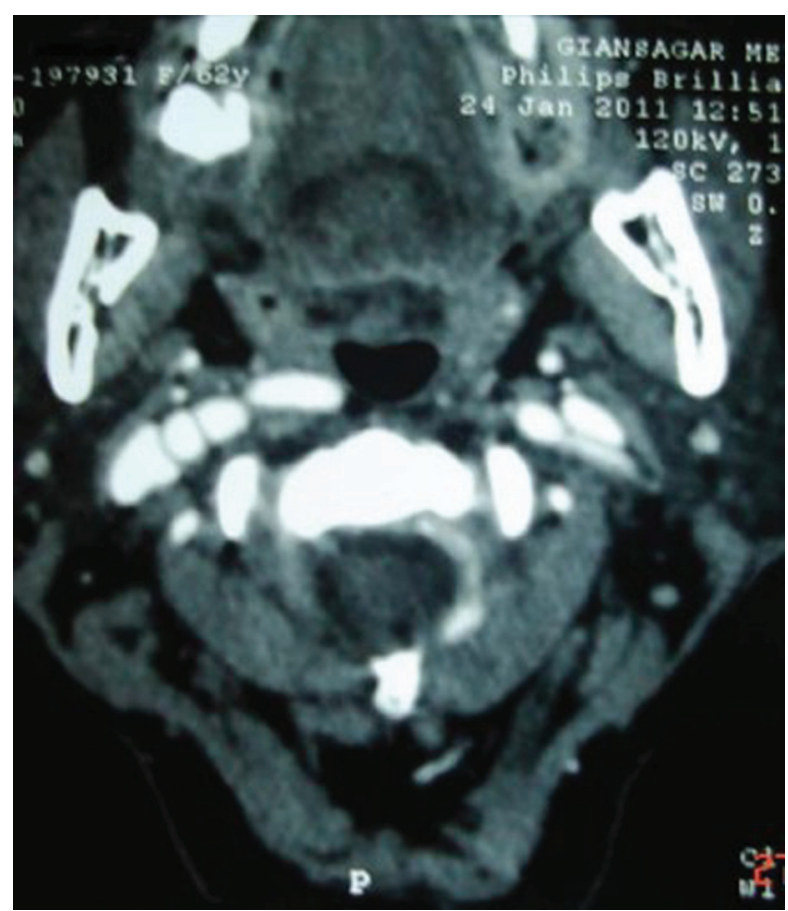

Figure 2 Axial CT section image showing looping of right ICA and its medial bulge into the right pharyngeal wall. 


\section{BMJ Case Reports}

be confused with unilateral tonsillitis, peritonsillar abscess or parapharyngeal neoplasm. It is extremely important to recognise such an entity before any oropharyngeal surgery, as inadvertent incision may lead to massive haemorrhage and even death. ${ }^{2}$

\section{REFERENCES}

1. Hosokawa S, Mineta $\mathrm{H}$. Tortuous internal carotid artery presenting as a pharyngeal mass. J Laryngol Otol 2010;124:1033-6.

2. Ceylan S, Salman S, Bora F. Anomaly of the internal carotid artery detected during tonsillectomy. J Craniofac Surg 2010;21:1638-9.

Competing interests None.

Patient consent Obtained.

This pdf has been created automatically from the final edited text and images.

Copyright 2011 BMJ Publishing Group. All rights reserved. For permission to reuse any of this content visit

http://group.bmj.com/group/rights-licensing/permissions.

BMJ Case Report Fellows may re-use this article for personal use and teaching without any further permission.

Please cite this article as follows (you will need to access the article online to obtain the date of publication).

Gupta M, Gupta M. A dangerous parapharyngeal mass. BMJ Case Reports 2011;10.1136/bcr.04.2011.4084, date of publication

Become a Fellow of BMJ Case Reports today and you can:

- Submit as many cases as you like

- Enjoy fast sympathetic peer review and rapid publication of accepted articles

- Access all the published articles

Re-use any of the published material for personal use and teaching without further permission

For information on Institutional Fellowships contact consortiasales@bmjgroup.com

Visit casereports.bmj.com for more articles like this and to become a Fellow 